\title{
Russian business groups: substitutes for missing institutions?
}

\author{
Andrei Shumilov ${ }^{1}$, Natalya Volchkova ${ }^{2}$
}

\section{December, 2004}

\begin{abstract}
Numerous evidence demonstrate that firms affiliated with business groups in emerging markets outperform their independent counterparts. One of the proposed explanations for such a phenomenon is the more advanced groups' internal markets structure compared to the rest of the economy. In this paper we test the hypothesis that internal capital markets within Russian business groups overcome the liquidity constraints problem widely spread outside groups. Our findings indicate that even if the groups' internal capital markets do exist in Russian business groups, their efficiency is rather doubtful and the access to external financing by firms affiliated with the groups is constrained.
\end{abstract}

\footnotetext{
${ }^{1}$ Center for Economic and Financial Research, 47 Nakhimovskiy prospect of. 720, Moscow, 117418, Russia, Tel. (+7095) 105 5002, Fax. (+7095) 105 5003, e-mail: ashumilov@cefir.ru

${ }^{2}$ Center for Economic and Financial Research, New Economic School, 47 Nakhimovskiy prospect of. 720 , Moscow, 117418, Russia, Tel. (+7095) 105 5002, Fax. (+7095) 105 5003, e-mail: nvolchkova@cefir.ru
} 


\section{Introduction}

Business groups of various nature and organization structure rule the economic life in many countries. Khanna and Ghemawat (1998) survey the existing studies and indicate a significant role of diversified business groups in a number of emerging market economies and in some developed as well.

While there are both theoretical and empirical evidence that firm's participation in business groups in developed countries could be value reducing (Scharfstein and Stein, 2000, Montgomery, 1994) there is substantial empirical evidence that business groups in developing countries surpass independent firms in terms of economic performance (Khanna, 2000, Khanna and Rivkin, 1999, Keister, 1998, Chang and Choi, 1988). The most popular explanations for this phenomena are: minority shareholder exploitation, market power, better treatment by national government and the alleviation of market imperfections by groups (Khanna and Ghemawat, 1998). A number of studies emphasize the group ability to overcome capital market underdevelopment typical for emerging economies by substituting it with efficient internal capital market. The theoretical justification for this comes from the idea that lower information asymmetry within groups compared to the rest of the economy could help to mitigate the problem of contract enforcement and reduce the severity of liquidity constraints for affiliated firms.

The obvious way to test the hypothesis of the better financial institutions within group is to study business groups in the economies with the least developed financial markets. And the example of Russian economy whose characteristic features are highly inefficient capital market and wide prevalence of business groups could serve for this purpose. In this paper we empirically test the hypothesis of efficiency of Russian groups' internal capital markets over the period 1999-2002. We do this by examining the difference in the liquidity constraints faced by Russian firms affiliated with business groups on one hand and independent firms on the other.

The only test of the hypothesis of better institutions within Russian groups compared to the rest of the economy that we are familiar with is that of Perotti and Gelfer (2001), who investigated the difference in investment-cash flow sensitivity between 
Russian firms affiliated with business groups and independent firms in 1995. Their finding is that investments positively and significantly depend on internal cash flows for standalone firms and firms from industrial groups, while this relation is significant and negative for groups with a hierarchical structure head by banks. Suggested interpretation for these results is that there is either an internal capital market within bank-led groups which redirects finances to firms with better investment opportunities, or the controlling bank opportunistically transfers the value.

There are however some concerns regarding these results. There are only 17 firms in this study, which belong to bank-led groups, and 17 firms from industry groups. Therefore the statistical significance of the results seems to be quite low.

Another problem with a methodology exploit by Perotti and Gelfer was first pointed out by Kaplan and Zingales (1997). Their argument is that empirically estimated investment-cash flow sensitivity can be significant and positive even if the firms under study do not face liquidity constraints. The reason is that since there are no ideal proxies of firms' investment opportunities and cash-flow itself can be a good proxy for this then an empirically estimated significant positive relation between cash flow and level of investments could hardly be interpreted as a measure of liquidity constraints. This argument seems to be especially important for emerging markets because of highly inefficient and narrow stock market whose data on firms capitalization we need to rely upon to estimate firms’ market-to-book ratios.

In order to perform an empirical comparison of two sets of firms in terms of their access to external financial resources that is not marked by the above endogeneity problem we use the test developed by Almeida et al. (2003). This test is based on the effect of financial constraints on firm policies and, particularly, on firm's decision to save cash out of incremental cash inflows. While constrained firms facing the uncertainty in the ability to get external funds as they would be required in the future will tend to save more cash from current cash flows, the unconstraint firms that are able more easily to get external funds should not base their decision about cash savings on cash inflows. Therefore we expect positive propensity to save from cash 
flows, or cash flow sensitivity of cash, to be observed in the set of liquidity constrained firms, and no such a dependence for unconstrained firms.

Applying this test to the Russian firms we compare the cash flow sensitivities of cash estimated on two samples of firms - firms affiliated with business groups and independently operating ones. We use data on 3815 Russian firms 435 out of which are affiliated to business groups. Our results show that over the period 1999-2002 there was no significant difference in the cash-flow sensitivity of cash between these two sets of firms, which can be regarded as evidence in favor of the inefficiency of internal financial markets within Russian business groups over this period of time. Comparing different types of business groups in the same respect we failed to find any significant difference among bank-led groups, foreign owned groups and the others.

The paper is organized as follows. In section II we review empirical evidence on the Russian business groups performance, section III discusses the methodology of the research and describes the data, and section IV presents empirical results. The last section concludes.

\section{Russian business groups}

The development of business groups in Russia started after the beginning of transition. The mass voucher privatization, whose declared objective was to create a diverse ownership structure in the economy, has actually served as an instrument for consolidation of ownership. Starting from 1993 this process was often accompanied by rough violations of law. Serious fighting over assets seemed to be over around 1998 when the heads of the largest Russian business groups declared that their main concern was the effective governance of acquired assets.

Their plans, however, were interrupted by the financial crisis of 1998. The worsening of liquidity problem because of ruble devaluation and GKO default brought about the reduction of stock ownership in a number of groups head by commercial banks. This, in turn, led to the new wave of ownership changes in Russian economy. An active participation of regional authorities in this redistribution was one of the most remarkable features of this period. At the same time a favorable situation in the 
international oil and other raw material markets starting from 1999 brought significant cash inflows to groups operating in extraction industries, which help them expand to other sectors, such as agriculture, automobiles, medicine, construction etc.

Boone and Rodionov (2001) analyzed the ownership structure and performance of a set of 64 largest Russian enterprises and found that while $43 \%$ of revenues originated in enterprises under state control, $41 \%$ of the remaining revenues were controlled by five largest industrial groups (Menatep, Interros, Russian Aluminium, Sistema and Alfa-Group). Guriev and Rachinskiy (2004) studied the ownership structure of 1700 largest Russian enterprises in 2001 and found that enterprises affiliated with 22 largest business groups employed $42 \%$ of labor and stood for $39 \%$ of sales. As far as the performance of business groups is concerned, the authors provide empirical evidence that business groups outperformed other private firms by about $9 \%$ in terms of TFP growth in 2002, while their productivity level was about the same as in other private firms.

Given the indications of better Russian groups' performance over standalone firms we ask the question whether it is better functioning of internal capital markets within groups that is responsible for this. In order to answer this question we compare the liquidity constraint problems experienced by firms affiliated to groups and non affiliated to judge the degree of improvement of groups' internal capital markets compared to the economy-wide one.

\section{Methodology and data}

Based on the availability of firm level accounting data Almeida et al. (2003) suggest empirical test for liquidity constraints that is derived from dynamic theoretical model in which firms facing both present and future investment opportunities might not have enough internally generated cash flows to finance them. Depending on the firm's ability to attract external capital, cash hoarding might be used to finance future investments. Comparing first-best solution for financially unconstrained firms with the solution for the firm facing external capital market frictions the authors find that, given the same investment opportunities, financially constrained firms should increase the stock of liquid assets in response to positive cash flow innovations, while 
unconstrained firms should not display any systematic behavior in managing their liquidity.

In terms of empirical application this result indicates that controlling for investment opportunities financially constrained firms should have significantly positive cash flow sensitivity of cash, while this sensitivity should be insignificant for firms that are able to rise external liquidity without any difficulties. At the same time the results of the theoretical model do not allow us to compare the severity of financial constraints faced by the firms based on the values of propensity to save cash out of cash flows. That is, given this approach, the only hypothesis that we are able to test is whether the group of firms under the question experience liquidity constraints or not.

This test can be reasonably applied to verify the hypothesis whether there are efficient internal financial markets within Russian business groups. Given that the economywide financial market is very limited and the costs of rising external financing for Russian firms are quite large, the existence of internal financial market within business group could allow affiliated firms to hoard up less cash.

In order to specify the empirical model for testing the above hypothesis we need, first of all, to control for the firms' investment opportunities. The most obvious way to do this is to use the stock market data on firms' market-to-book ratios as a proxy for firm's investment demand. This approach being very useful and popular in developed economies has significant drawbacks while being applied for transition economies. First of all, the underdeveloped financial market implies the significant distortions of stock prices. Secondly, relying on stock market data we limit ourselves to a small dataset of firms that have frequent enough market quotations. Facing this problem we choose to apply the accelerator model of investment demand for the study. It is worth to mention that Lizal and Svejnar (1997) pointed out the workability of accelerator model framework in transition economies when analyzed the firm-level investment behavior of Czech firms.

Given the significant variation of firms by their total asset size and following the approach of Almeida et al.(2003) we include the firm size as a control variable in the model following the argument that larger firms tend to have less cash to total asset 
ratios because of their easier access to external financial markets (Opler et al., 1998). The importance of the firm's size as one of the determinant of its financial constraints has been also demonstrated in the study of Russian Financial-Industrial Groups by Volchkova (2001).

Therefore the basic relationship we test in the paper has the following form.

Changes in cash holding ${ }_{i t}=\alpha+\beta^{*}$ Cash flow $_{i t}+\gamma^{*}$ Cash flow $_{i t}{ }^{*} D_{\text {business groupit }}{ }^{+}$

$+\delta^{*}$ Size $_{i t}+\mu^{*}$ Changes in sales $i t+v^{*}$ Changes in sale $_{i, t-1}+\varepsilon_{i t}$

where all variables except Size are normalized to the value of firm $i$ total assets. Changes in cash holding stands for the change in firm's cash reserves over the year, cash flow is estimated as firm's operating cash flow over the year and Size is the logarithm of firm's total assets. Changes in sale and Changes in sale ${ }_{-1}$ are current year and previous year changes in firm's sales respectively, that is, we proxy investment opportunities by two lags of changes in sales. $D_{\text {business group }}$ is a dummy variable that is equal to 1 if the firm belongs to some business group during the year and 0 otherwise.

The hypothesis that firms affiliated with groups have access to internal group's financial market will be tested by estimating the value of propensity to save out of cash flow for unaffiliated firms, $\beta$, and comparing it with that of affiliated firms, $\beta+\gamma$. If the hypothesis that $\beta>0$ and $\beta+\gamma=0$ would not be rejected we could interpret the results in the way that while independent Russian firms face liquidity problem because of underdeveloped capital market the affiliation of firms with business groups helps to overcome the problem of getting external financing. In order to be consistent with the theoretical model of Almeida et al. (2003), which provides the foundation for the empirical test, we consider only those firms that have positive operating cash flow in the year in question.

To test the hypothesis we use annual data for Russian manufacturing joint-stock companies available from the Disclosure Program administered by the Federal Commission for Security Markets (FCSM), which requires JSC to submit balance sheets, financial statements and information on ownership structure, board of 
directors and management. On the basis of these reports we have constructed a database of annual balance sheets and financial statements for the period from 1996 to 2002 , which originally contained 21,470 observations for 4,866 manufacturing firms.

For comparison of liquidity constraints between business groups and the rest of the economy we have constructed a list of business groups' affiliates, with dates of their entry to or exit from the group. To distinguish between group and non-group firms we used the following criteria. Firstly, we identified major business groups and their core affiliates according to the information from leading experts on Russian business groups (Pappe, 2000). Then on the basis of information about ownership structure from FCSM reports in the business groups' list we added those firms, whose major shareholders were group affiliates identified at the first stage. As in a number of occasions major shareholders were nominal owners or offshore firms, we also used information about affiliations of firms' managers and members of boards of directors. Finally, we tracked articles mentioning firms' entries to or exits from business groups in Russian journals and newspapers during the period of 1996-2002. In addition to identifying domestic business groups, we classified firms owned by big foreign companies (such as Procter\&Gamble, ICN Pharmaceuticals, etc.) as a special group. We ended up with a data set of 674 manufacturing firms affiliated with business groups, whose reports were presented in the FCSM database.

After cleaning for missing data and checking for data consistency we get a set of 3815 firms out of which 435 firms are on the list of groups' affiliates. By differentiating groups' firms based on the specifics of groups' ownership we single out 141 firms in bank-led groups and 42 firms from groups owned by foreigners.

As a measure of investment in fixed assets we used a sum of fixed assets installed during the current year and changes in unfinished construction. Operational cash flow is measured as net profits from operations minus changes in inventories minus changes in receivables plus changes in payables plus depreciation expenses minus tax on profit. Level of cash holdings is estimated as the sum of short-term financial 
investments plus cash. In order to get real changes in firm performance we used producer price indices.

Table 1 shows descriptive statistics for the resulting sample of firms for 2001. As seen from the table, group affiliated firms are on average several times larger than non-group firms, irrespective of whether the size is measured in terms of sales, employment or total assets. Nevertheless, ratios of investment, cash flow and cash holdings to total assets are statistically the same for both groups. Among the performance statistics the only one in terms of which groups' and stand-alone firms behave differently is changes in sales scaled by total assets which is much higher for non-group firms than for groups' affiliates. However, if we take into account that group firms are much bigger than independent ones this fact can hardly be surprising.

\section{Estimation results}

We first run a basic changes in cash holding regression (1). Table 2 presents the results of panel data estimations with fixed effects and year dummies for 1999-2002.

The results support our hypothesis that Russian firms face liquidity constraints. We obtained positive and statistically significant propensity to save out of cash flows. The coefficients of changes in sales are significant and positive, which is also expected in the framework of accelerator model of investment demand: an increase in sales today is one of the main determinants of investment demand increase tomorrow, so firms need to hoard more cash today to meet tomorrow's demand.

The size of the firm has no significant effect on changes in cash stock in the sample of firms in this study. A possible explanation for this is that the effect of size on liquidity constraints in underdeveloped capital markets becomes distinguishable only after some threshold level of the firm size is passed and the additional research for this is required.

The estimated coefficient, which interests us most, is at cash flow variable interacted with business group dummy and it is insignificant. It implies that firms affiliated with Russian business groups had similar propensity to save cash out of cash flows as their independent counterparts over the period 1999-2002. That is the groups' firms face 
liquidity constraints as well as the firms in the rest of the economy. Based on this result we are not able to conclude that there are no internal capital markets within groups. However we can argue that they are inefficient.

In their study of Russian business group performance compared to the rest of the economy Guriev and Rachinskiy (2004) and Perotti and Gelfer (2001) distinguish among several types of business groups and in several occasions find the difference in performance of groups owned by foreigners compared to other groups and bank-led groups compared to industry groups. Therefore in our second test we run regressions only on groups' affiliated firms to compare the propensity to save out of cash flow, first, between bank-led groups and the rest of the groups and, second, between business groups owned by foreigners and the rest of the groups. For these purposes we introduce the corresponding dummy variables and interact them with the cash flow variable.

The results are presented in tables 3 and 4 respectively. In both estimations we find the significant positive propensities to save out of cash flows for the whole sample and insignificant coefficients at interacted variables. Therefore the hypothesis of unconstrained behavior of foreign-owned and bank-led business groups' affiliated firms is not supported. These results allow us to conclude that the type of group, which the firm belongs to, has no effect on the firm's decision to save cash out of cash flow. That is, firms in bank-led groups or firms affiliated with foreign-owned groups that are liquidity constrained increase the cash stock out of current cash flows to be able to finance their needs afterwards.

We check the robustness of the results by running similar regressions on each type of firms (standalone, groups' affiliated, bank-led groups) separately and find that in all cases the coefficient of cash flow is significant and positive. We also perform the test for firms with positive cash flows and get a support for the above results.

\section{Conclusions}

In the paper we test a hypothesis that firms in Russian business groups have easier access to external financing within the groups compared to the rest of the economy, which allows them to overcome the liquidity constraint problem. The empirical 
results however do not support this hypothesis. Although we cannot conclude that internal capital markets within Russian groups do not exist, we can argue that if such markets exist within groups their efficiency in terms of relaxation of liquidity constraints for affiliated firms is not revealed over the period of 1999-2002.

This result seems to counter a common view that assumes the existence of internal capital markets within business groups to which affiliated firms have an easy access even if the capital markets outside the groups are underdeveloped. Our study shows that it is not the case for the Russian economy.

We argue that superior performance of Russian business groups relative to the rest of the economy observed in earlier studies could not be attributed to more efficient capital markets within the groups. Other sources of groups' better performance need to be verified since the internal capital markets within Russian business groups, if they exist at all, are seems not to be the substitute for underdeveloped financial institutions outside the groups.

\section{Acknowledgements}

We would like to thank Yakov Pappe for his incredible generosity in sharing his knowledge of Russian business groups with us, Sergei Golovan for invaluable help in handling the data and Luigi Zingales for very useful suggestions.

\section{References}

Almeida, H., Campello, M. and Weisbach, M. (2003), “The cash flow sensitivity of cash”, Journal of Finance, 59, p. 1777-1804

Boone, P. and Rodionov, D., 2001, "Rent seeking in Russia and the CIS", Brunswick UBS Warburg, Moscow

Chang, J. and Choi, U., 1988, "Strategy, structure and performance of Korean business groups: a transaction cost approach”, Journal of Industrial Economics, Vol. 37, No. 2, p.141-158

Guriev, S. and Rachinskiy, A., 2005, “Oligarchs: the past or the future of Russian capitalism?”, forthcoming in Journal of Economic Perspectives

Keister, L., 1998, "Engineering growth: business group structure and firm performance in China's transition economies”, American Journal of Sociology, 104(2), p. 404-440 
Khanna, T., 2000, "Business groups and social welfare in emerging markets: existing evidence and unanswered questions”, European Economic Review, 44, p. 748-761

Khanna, T. and Ghemawat, T., 1998, "The nature of diversified business groups: a research design and two case studies", Journal of Industrial economics, Vol. 46, No. 1 , p. 35-61

Khanna, T. and Rivkin, J., 1999, "Estimating the performance effects of groups in emerging markets”, HBS Working Paper

Kaplan, S. and Zingales, L., 1997, "Do financial Constraints explain why investment is correlated with cash flow?" Quarterly Journal of Economics, 115, p. 565-592

Lizal, L. and Svejnar, J. 1997, "Enterprise investment during the transition: evidence from Czech panel data”, WDI Working Paper \# 60a

Montgomery, C. 1994, “Corporate diversification”, Journal of Economic Perspectives, 8(3), p. 163-178

Opler, T., Pinkowitz, L., Stulz, R. and Williamson, R., 1999, “The determinants and implications of corporate cash holdings”, Journal of Financial Economics, 52, p. 3-46

Pappe, Y., 2000, "The oligarchs", Higher School of Economics, Moscow (in Russian)

Perotti, E. and Gelfer, S., 2001, "Red barons or robber barons? Governance and investment in Russian financial-industrial groups", European Economic Review, 45, p. $1601-1617$

Scharfstein, D. and Stein, J. 2000, "The dark side of internal capital markets: divisional rent-seeking and inefficient investment”, Journal of Finance, 55(6), p. 2537-2564

Volchkova, N., 2001, "Does Financial-Industrial Group Membership Affect Fixed Investment: Evidence from Russia”, CEFIR Working Paper 
Table 1. Descriptive statistics ${ }^{3}$

\begin{tabular}{|c|c|c|c|c|}
\hline Statistics (2001) & & Total sample & $\begin{array}{l}\text { Group } \\
\text { affiliates }\end{array}$ & $\begin{array}{l}\text { Non-group } \\
\text { firms }\end{array}$ \\
\hline Number of firms & & 2529 & 355 & 2174 \\
\hline \multirow[t]{3}{*}{ Sales, bln. roubles } & mean & 1.007 & 4.403 & 0.449 \\
\hline & std.dev. & 5.37 & 12.85 & 2.076 \\
\hline & median & 0.142 & 1.28 & 0.112 \\
\hline \multirow[t]{3}{*}{ Employment, thous. } & mean & 1.719 & 5.421 & 1.108 \\
\hline & std.dev. & 5.028 & 11.099 & 2.56 \\
\hline & median & 0.549 & 2.198 & 0.459 \\
\hline \multirow{3}{*}{$\begin{array}{l}\text { Total assets (beg.of year), bln. } \\
\text { roubles }\end{array}$} & mean & 1.401 & 5.788 & 0.68 \\
\hline & std.dev. & 11.19 & 19.78 & 8.836 \\
\hline & median & 0.13 & 1.845 & 0.1 \\
\hline \multirow[t]{3}{*}{ Investment/Total assets } & mean & 0.095 & 0.102 & 0.094 \\
\hline & std.dev. & 0.179 & 0.138 & 0.185 \\
\hline & median & 0.047 & 0.051 & 0.046 \\
\hline \multirow[t]{3}{*}{ Cash flow/Total assets } & mean & 0.088 & 0.083 & 0.089 \\
\hline & std.dev. & 0.211 & 0.223 & 0.209 \\
\hline & median & 0.073 & 0.063 & 0.077 \\
\hline \multirow{3}{*}{$\begin{array}{l}\text { Cash holdings/Total assets (beg.of } \\
\text { year) }\end{array}$} & mean & 0.04 & 0.044 & 0.039 \\
\hline & std.dev. & 0.077 & 0.083 & 0.076 \\
\hline & median & 0.013 & 0.013 & 0.013 \\
\hline \multirow{3}{*}{$\begin{array}{l}\text { Change in cash holdings(beg.-end of } \\
\text { year)/Total assets }\end{array}$} & mean & 0.011 & 0.019 & 0.009 \\
\hline & std.dev. & 0.077 & 0.1 & 0.072 \\
\hline & median & 0.001 & 0.001 & 0.001 \\
\hline \multirow{3}{*}{$\begin{array}{l}\text { Change in sales (2001-2000)/Total } \\
\text { assets }\end{array}$} & mean & 0.044 & 0.013 & 0.05 \\
\hline & std.dev. & 0.478 & 0.449 & 0.482 \\
\hline & median & 0.025 & 0.014 & 0.029 \\
\hline
\end{tabular}

\footnotetext{
${ }^{3}$ The number of firms for which descriptive statistics are presented in this table differs from the one mentioned in the paper because not all firms in the data set have data reported for all years in a row.
} 
Table 2. Cash flow sensitivity of cash: business groups’ affiliated firms vs. standalone firms

Dependent variable: Changes in cash holding

Independent variables scaled by total assets

Operating cash flow

0.082

$(0.005)^{* * *}$

Operating cash flow * Dummy for business groups

0.006

(0.013)

Changes in sales

0.011

$(0.002) * * *$

Changes in sales in previous year

$-0.002$

(0.002)

Size

0

$(0.000)^{* * *}$

Constant

0.007

$(0.002)^{* * *}$

Observations

10139

Number of firms corrected

3815

R-squared

0.06

Standard errors in parentheses

* significant at $10 \%$; ** significant at $5 \%$; *** significant at $1 \%$ 
Table 3 Cash flow sensitivity of cash: bank-led groups' affiliated firms vs. the other affiliates

Dependent variable: Changes in cash holding

\section{Independent variables scaled by total assets}

Operating cash flow

0.095

$(0.017)^{* * *}$

Operating cash flow * Dummy for business groups

$-0.014$

(0.035)

Changes in sales

0.011

(0.007)

Changes in sales in previous year

0.01

(0.007)

Size

0

$(0.000) * * *$

Constant

0.011

$(0.006)^{*}$

Observations

1308

Number of firms corrected

435

R-squared

0.06 
Table 4 Cash flow sensitivity of cash: foreign-owned groups' affiliated firms vs. the other affiliates

Dependent variable: Changes in cash holding

\section{Independent variables scaled by total assets}

Operating cash flow

0.076

$(0.018) * * *$

Operating cash flow* Dummy for business groups

Changes in sales

0.011

(0.007)

Changes in sales in previous year

0.011

(0.007)

Size

0

$(0.000) * * *$

Constant

0.012

$(0.006)^{*}$

Observations

1308

Number of firms corrected

435

R-squared

0.06

Standard errors in parentheses

* significant at $10 \%$; ** significant at $5 \%$; *** significant at $1 \%$ 